\title{
Study of Aluminum Corrosion in Chloride and Nitrate Media and its Inhibition by Nitrite
}

\author{
S. N. Afzal ${ }^{\text {* }}$, M. A. Ali Shaikh ${ }^{1}$ C. M. Mustafa ${ }^{2}$, M. Nabi, \\ M. Q. Ehsan ${ }^{1}$ and A. H. Khan ${ }^{1}$ \\ 1. Department of Chemistry, University of Dhaka, Dhaka-1000, Bangaladesh. \\ 2. Department of Applied Chemistry, University of Rajshahi, Bangaladesh. \\ 3. Department of Chemistry, BIT, Khulna, Bangladesh.
}

\begin{abstract}
Aluminum corrosion has been studied in aqueous chloride and nitrate media. Potentiodynamic method is applied to carry out the individual effect of chloride and nitrate ions on the commercial grade aluminum corrosion. In both chloride and nitrate media the corrosion behavior is affected at $\mathrm{pH} 4$ and 10. The corrosion rate of aluminum increases with the increase of concentrations of chloride and nitrate ions. In both media corrosion behavior is significant at higher $\mathrm{pH}$ value due to the instant dissolution of metal ions as complex. The nitrite plays an important role as a corrosion inhibitor in both chloride and nitrate media.
\end{abstract}

\section{Introduction}

Aluminum is one of the widely used corrosion- resistant metals. The hard and tough oxide film formed on the surface of the aluminum make it resistant to corrosion. If the protective effect of the oxide film is overcome by scratching or by amalgamation, it is attacked under ordinary conditions by hot alkali hydroxides, halogen, various non-metals and even by water. Traces of $\mathrm{Cu}^{2+}$ or $\mathrm{Fe}^{3+}$ in water react with aluminum, depositing metallic copper or iron on the aluminum surface. ${ }^{1}$ Ender et. al studied at $\mathrm{pH}<4, \mathrm{Al}^{3+}$ ions are stable and at $\mathrm{pH}>8.5$ aluminates ions appear while in the $\mathrm{pH}$ range 4.5-8.5 alumina hydrates predominates. ${ }^{2}$ It has been reported that the addition of the aggressive anions like chlorides, thiocyanate, hydroxide, sulfide, nitrate, formate and acetate leads to extensive localized attack in all the cases. ${ }^{3}$ The breakdown of the passive film makes the migration of aggressive anions to reach the metal-film interface more favorable. As a result, aluminum ion forms compound with the aggressive anions that get dissolve in the medium subsequently.

The corrosion rate of aluminum depends mainly on the thickness of the oxide layer and its compactness or crystallographic structure. The corrosion process is also influenced by the electric change of the surface. It is known that the charge on the surface of the oxidized aluminum is the consequence of the interaction of the oxide and the 
surroundings. The results of the former investigations of the anodic oxidized aluminum have shown that the charge of the surface depends on the oxidation process. ${ }^{4}$

The artificial crevice of aluminum electrodes were potentiostatically polarized over a wide range of potential in $0.1 \mathrm{M} \mathrm{NaCl}$ solution with and without dichromate ions. The initial dissolution of aluminum in a crevice was ohmic controlled. From the change in the dissolution current with time, the condition of the crevice and potential at the bottom of crevice were established. The condition and the bottom potential decreased with the ratio of cathodic charge of hydrogen evaluation. ${ }^{5}$

Nitrites are well- defined oxidizing agents. They are effective as corrosion inhibitor for aluminum due to powerful oxidizing properties. This reveals that oxide layer on the aluminum surface plays an important role on its corrosion in aggressive media. ${ }^{1}$ Foley et $a l^{6}$ investigated that in chloride solution the high energy aluminum metal ionizes rapidly to the $\mathrm{Al}^{3+}$ ion, which also hydrolyses rapidly. These two species react further to from a reasonable stable basic aluminum chloride that is transformed slowly to $\mathrm{Al}(\mathrm{OH})_{3}$ and finally to $\mathrm{Al}_{2} \mathrm{O}_{3} \cdot \mathrm{H}_{2} \mathrm{O}$ which plays an important role for passivation of aluminum. Bhattarai studied that the nature of the passive films formed on the metal alloys plays a vital role for high corrosion resistance of the alloys. ${ }^{7}$ The high chemical reactivity of the alloys lead to the rapid accumulation of beneficial species in the passive film. Bronzoi et al studied that localized corrosion can be prevented by the action of adsorption inhibitors which prevent the adsorption of aggressive anions or by the formation of a more resistant oxide film on the metal surface. ${ }^{3}$ Pitting type corrosion of aluminum alloys is reduced in the presence of most investigated inhibitors. The adsorption of most inhibitors is also found to obey Langmuir's adsorption isotherm. It was found that lower concentration of inhibitors inhibited efficiently than higher concentration for aluminum alloys. ${ }^{8}$ Kharafi et al. observed that a series of inhibitors like molybdate and dichromate were found effective in passivating the aluminum metal or alloy surface. ${ }^{9}$ But, now a days as these inhibitors are toxic for environment, it is encouraged to avoid the use of such inhibitors.

\section{Experimental Methods}

Commercial grade aluminum ( $\mathrm{Al} 97 \%$ and trace amount of $\mathrm{Fe}, \mathrm{Cu}, \mathrm{Zn}$ and $\mathrm{Ga}$ ) with $2 \mathrm{~mm}$ diameters and approximately $10 \mathrm{~cm}$ long was used to conduct this work. One side of the electrode was keep open for exposure to the aqueous medium and other side was free to make electrical connection. The exposure side of the electrode was polished with aluminum and silicon powder like mirror finish. The open side of the electrode was soaked for 1 hour in $20 \mathrm{~mL}$ base electrolyte or inhibitor solutions. ${ }^{10}$ Before starting the experiment, the open circuit potential/rest potential (OCP) was measured using a petentiostat (model HQ-2040) and data were obtained by using computer controlled electrochemical system made by Advanced Analytics, USA. ${ }^{11}$

The aggressive ion solutions and inhibitor solutions were prepared by dissolving the appropriate amount of chloride, nitrate and nitrite salts in de-ionized water. The study of corrosion behavior of aluminum was carried out in different concentrations of 
chloride, nitrate and nitrite solutions. After soaking the electrode in the aforementioned solutions (chloride and nitrate), it was taken with reference electrode as a three- electrode electrochemical cell system and completed the rest of the procedure.

The voltammetric cell used is a three-electrode electrolytic cell (capacity $50 \mathrm{~mL}$ ) made of borosilicate glass with a Teflon cap from bio-analytical system (BAS), USA. The working electrode was made of commercial grade aluminum (Al 97\% and trace amount of $\mathrm{Fe}, \mathrm{Cu}, \mathrm{Zn}$ and $\mathrm{Ga}$ ). The reference electrode was $\mathrm{Ag} / \mathrm{AgC1}$ (saturated $\mathrm{NaCl}$ ) and Pt wire was used as counter electrode.

\section{Results and Discussion}

\section{Corrosion behavior of aluminum in chloride medium}

Potentiodynamic sweep experiments on aluminum were carried out in chloride ion solutions of different concentrations at different $\mathrm{pH}$ values. All experiments were carried out after 1 hour soaking of the aluminum electrode in the same way. The results are reported as log current vs potential and corrosion potential vs concentration graphs. Log current vs potential graphs are illustrated in Fig. 1, where aggressiveness of $\mathrm{CI}^{-}$ion on aluminum corrosion is observed at $\mathrm{pH}$ 10. Higher current is observed at higher concentration of chloride ion indicating enhancement of corrosion rate. Figure 2 represents the effect of chloride ion concentration (aqueous 500, 1000 and $2000 \mathrm{ppm}$ aqueous chloride solution) on the corrosion potential of aluminum at $\mathrm{pH} \mathrm{4,6}$ and 10. For all the $\mathrm{pH}$ values the lowest potential (more negative) was observed for $2000 \mathrm{ppm}$ chloride medium. In general, more negative potential indicates more corrosion of the metal. The result showed more negative potential at higher $\mathrm{pH}$ then those at lower $\mathrm{pH}$ values. At $\mathrm{pH} 10$ (the highest $\mathrm{pH}$ used in this study) the corrosion potential decreases significantly with the increase of chloride concentrations. This means that at relatively stronger alkaline media the surface oxide layer was more soluble as aluminate in the chloride medium than those in acidic medium. As a result, the metal surface exposed to the aggressive medium corroded severely. The dissolution of aluminum oxide in alkaline medium can be presented as: ${ }^{1}$

$$
\begin{array}{ll}
\mathrm{Al}_{2} \mathrm{O}_{3}+2 \mathrm{OH}^{-} & =\mathrm{AlO}_{2}^{-}+\mathrm{H}_{2} \\
\mathrm{Al}+\mathrm{O}_{2}+2 \mathrm{H}_{2} \mathrm{O} & =\mathrm{Al}^{3+}+4 \mathrm{OH}^{-} \\
\mathrm{Al}^{3+}+3 \mathrm{Cl}^{-} & =\mathrm{AlCl}_{3}
\end{array}
$$

In acidic condition, the reaction can be represented as ${ }^{6}$ :

$$
\begin{array}{ll}
\gamma \cdot \mathrm{Al}_{2} \mathrm{O}_{3} \cdot \mathrm{H}_{2} \mathrm{O} & =\mathrm{Al}(\mathrm{OH})_{3} \\
\mathrm{Al}(\mathrm{OH})_{3}+\mathrm{HCl} & =\mathrm{Al}(\mathrm{OH})_{2} \mathrm{Cl}+\mathrm{H}_{2} \mathrm{O} \\
\mathrm{Al}(\mathrm{OH})_{2} \mathrm{Cl}+\mathrm{H}^{+}=\mathrm{Al}(\mathrm{OH}) \mathrm{Cl}^{+}+\mathrm{H}_{2} \mathrm{O} \\
\mathrm{Al}(\mathrm{OH})_{2} \mathrm{Cl}+2 \mathrm{H}^{+}=\mathrm{AlCl}^{++}+2 \mathrm{H}_{2} \mathrm{O}
\end{array}
$$




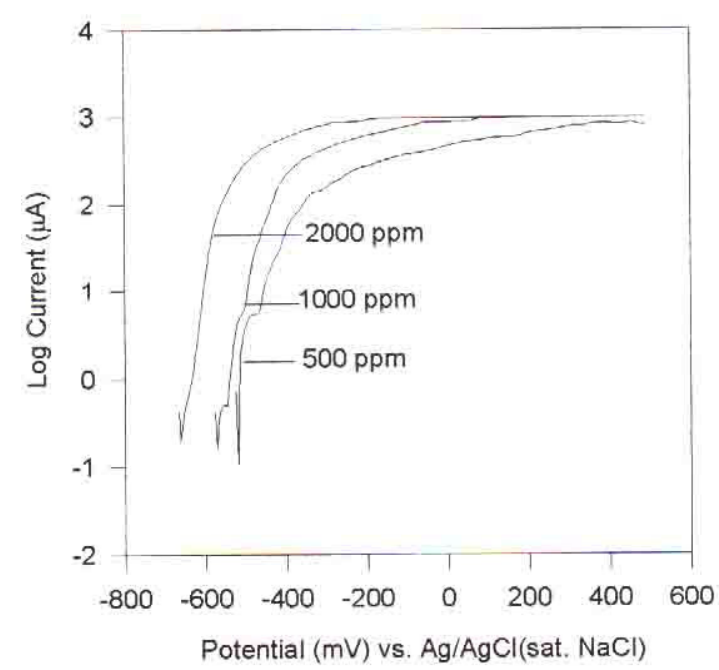

Figure 1: Corrosion behavior of aluminum in

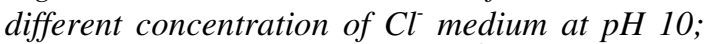
soaking time $1 \mathrm{~h}$; area $3 \mathrm{~mm}^{2}$; temperature: $20 \pm 2^{0} \mathrm{C}$.

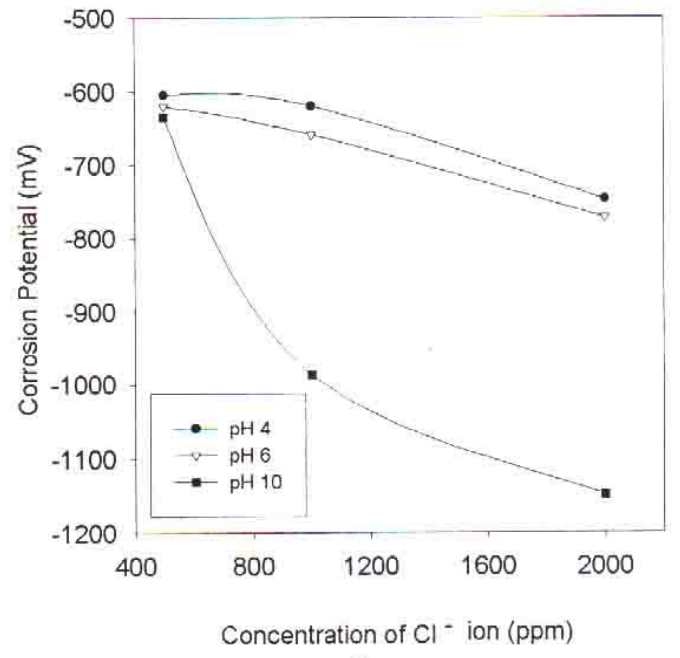

Figure 2: Effect of concentration of $\mathrm{Cl}^{-}$ion on the corrosion potential of aluminum at different pH; soaking time $1 \mathrm{~h}$; area $3 \mathrm{~mm}^{2}$; temperature: $20 \pm 2^{\circ} \mathrm{C}$.

\section{Corrosion behavior of aluminum in nitrate medium}

The corrosion behavior of aluminum in nitrate ion was investigated by the potentiodynamic measurements. Corrosion behavior was studied after 1 hour soaking of the electrode which is shown in Fig. 3. It shows clearly the aggressiveness of nitrate medium on aluminum at $\mathrm{pH} 10$. Here, the current gradually increases with the increase of potential. The nature of the degree of corrosion is indicated by the increase in corrosion current at different concentration of nitrate ion. The effect of nitrate ion concentration on corrosion potential of aluminum in aqueous nitrate ion concentration 500, 1000 and $2000 \mathrm{ppm}$ were investigated at $\mathrm{pH} \mathrm{4,6}$ and 10. The highest corrosion current was observed for $200 \mathrm{ppm}$ of nitrate ion concentration. In initial, corrosion current increases in the active region as the potential is increased. After this increases in current, it remained constant up to a certain potential. This is the passive region. Beyond this region there is further increase of current with increasing potential, indicating the transpassive region. These phenomena were observed in all the cases. Though, it is rather unrespectable but somehow the corrosion product did not dissolve as produced on the surface, which acts as a barrier layer continuing the reactions.

The differences of corrosion potential (OCP) among the three $\mathrm{pH}$ values are illustrated in Fig. 4. More negative potentials are observed at $\mathrm{pH} \mathrm{10,} \mathrm{whereas} \mathrm{less}$ negative potential values at $\mathrm{pH} 4$. It seems that aluminum is highly corrosive at higher $\mathrm{pH}$ values than that at lower $\mathrm{pH}$ values. It means in nitrate medium also the aluminum is corroded sharply at higher $\mathrm{pH}$ as the surface oxide layer destroyed instantly. Inhibitive behavior of nitrite ion on aluminum corrosion in aggressive media. 


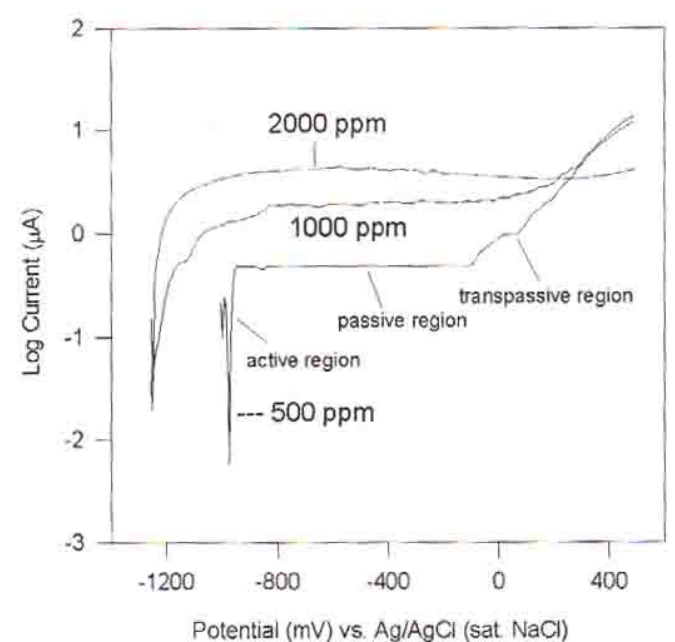

Figure 3: Corrosion behavior of aluminum in different concentration of $\mathrm{NO}_{3}^{-}$medium at $\mathrm{pH} 10$; soaking time $1 \mathrm{~h}$; area $3 \mathrm{~mm}^{2}$; temperature: $20 \pm 2^{0} \mathrm{C}$.

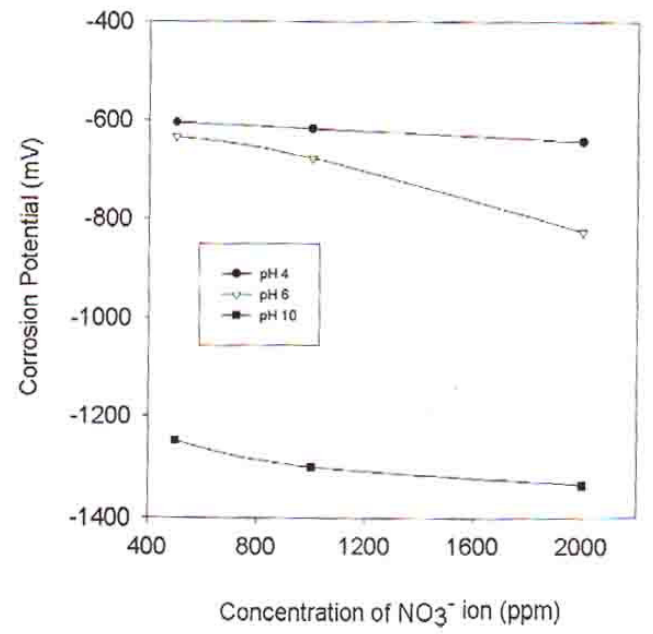

Figure 4: Effect of concentration of $\mathrm{NO}_{3}{ }^{-}$ion on the corrosion potential of aluminum at different pH; soaking time $1 \mathrm{~h}$; area $3 \mathrm{~mm}^{2}$; temperature: $20 \pm 2^{0} \mathrm{C}$.

\section{Inhibitor behavior of nitrite ion on aluminum corrosion in aggressive media}

It has been reported that localized corrosion of aluminum surface can be prevented by the action of adsorptive inhibitors, which prevent the adsorption of the aggressive anions or by the formation of a more resistant oxide film on the metal surface. $^{3}$

The corrosion inhibition as well as passivation of aluminum by nitrite ion in aqueous medium containing $500 \mathrm{ppm} \mathrm{Cl}^{-}$ion was examined and the observation are presented in Fig. 5. Experiments were conducted at $\mathrm{pH} 10$ for different concentrations of $\mathrm{NO}_{2}{ }^{-}$ion $(250,500,1000$ and $2000 \mathrm{ppm})$. The inhibition is more significant with the higher concentration of $\mathrm{NO}^{2-}$ ion as shown in this figure. The corrosion potential vs concentration of nitrite ion is plotted in Fig. 6. It is observed that the inhabitation is more significant at lower $\mathrm{pH}(\mathrm{pH}<6)$ and less significant at higher $\mathrm{pH}(\mathrm{pH} \geq 10)$. The passivation mechanism can be presented as: ${ }^{1}$

$$
2 \mathrm{NO}_{2}^{-}+2 \mathrm{H}^{+}+\mathrm{Al}_{\text {surface }} \rightarrow \mathrm{NO}+\mathrm{H}_{2}+\mathrm{O}_{\text {ads. on Al surface }}
$$




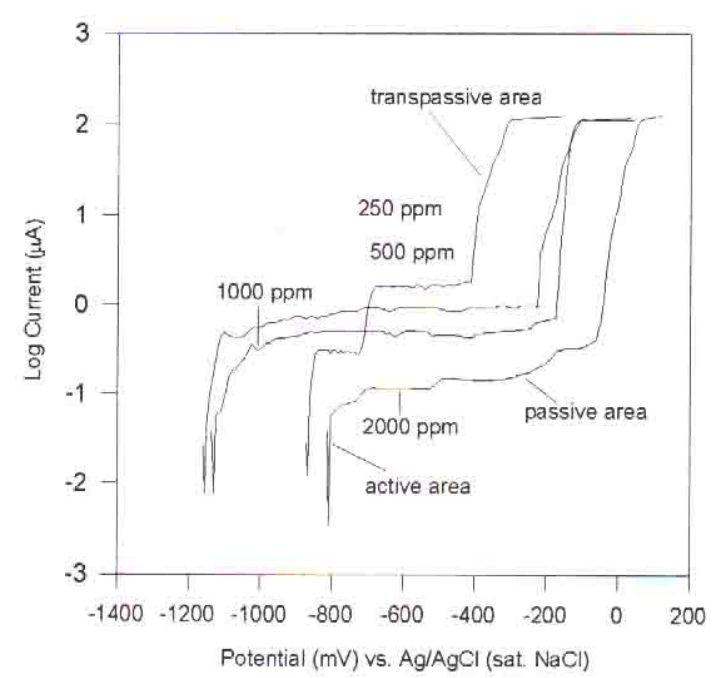

Figure 5: Inhibition of aluminum corrosion by $\mathrm{NO}_{2}{ }^{-}$ion of different concentration in 500 ppm of $\mathrm{Cl}^{-}$medium at $\mathrm{pH} 10$; soaking time $1 \mathrm{~h}$; area $3 \mathrm{~mm}^{2}$; temperature: $20 \pm 2^{\circ} \mathrm{C}$.

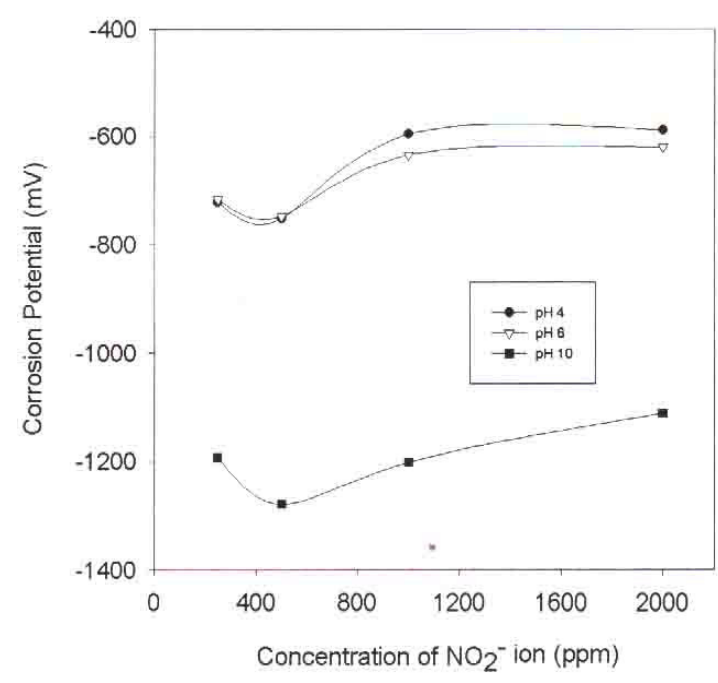

Figure 6: Effect of concentration of $\mathrm{NO}_{2}^{-}$ion on the corrosion potential of aluminum in $500 \mathrm{ppm}$ $\mathrm{Cl}$ medium at different $\mathrm{pH}$; soaking time $1 \mathrm{~h}$; area $3 \mathrm{~mm}^{2}$; temperature: $20 \pm 2^{\circ} \mathrm{C}$.

Identical experiments were also carried out to observe the inhibition effect of nitrite ion on aluminum corrosion in $1000 \mathrm{ppm} \mathrm{Cl}^{-}$medium at $\mathrm{pH} 10$ ( Fig .7). The effect of nitrite ion concentration $(500,1000$ and $2000 \mathrm{ppm})$ on the corrosion potential (OCP) at different $\mathrm{pH}$ is shown in Fig. 8. It is clear that the passivation is more effective at lower $\mathrm{pH}$ values $(\mathrm{pH}<6)$. The result demonstrates that aluminum is more active in alkaline medium than that in acidic medium.

The effect of nitrite ion concentration on aluminum corrosion inhibition in 550 ppm nitrate medium were examined at $\mathrm{pH} 6$ at room temperature range. The change of corrosion potentials with different concentrations of nitrite ion are shown in Fig. 9. The reaction mechanism would be similar as mentioned in the case of aluminum corrosion inhibition. The inhibition phenomena observed more significant at lower $\mathrm{pH}(\mathrm{pH} \leq 6)$ and less significant at higher $\mathrm{pH}(\mathrm{pH}>6)$.

Identical investigations were done in $1000 \mathrm{ppm} \mathrm{NO}_{2}{ }^{-}$medium. The result shown in Fig.10, demonstrate almost similar indications that corrosion inhibition is stronger at higher concentration of $\mathrm{NO}_{2}{ }^{-}$ion than at lower concentration. Better performance of inhibition is observed at $\mathrm{pH} \leq 6$ among $\mathrm{pH} 4,6$ and 10 . 


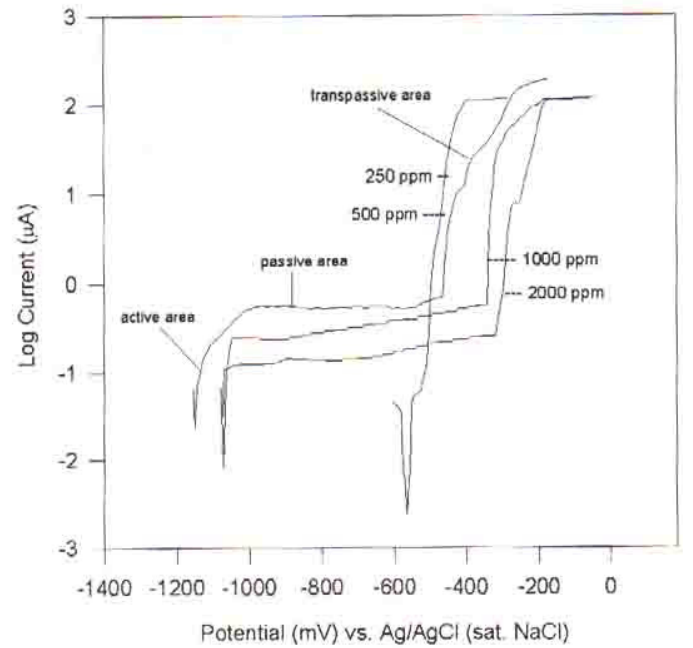

Figure 7: Effect of varying concentration of $\mathrm{NO}_{2}$ in $1000 \mathrm{ppm}$ of $\mathrm{Cl}^{-}$medium at $\mathrm{pH} \mathrm{10}$; soaking time $1 \mathrm{~h}$; area $3 \mathrm{~mm}^{2}$; temperature: $20 \pm 2^{\circ} \mathrm{C}$.

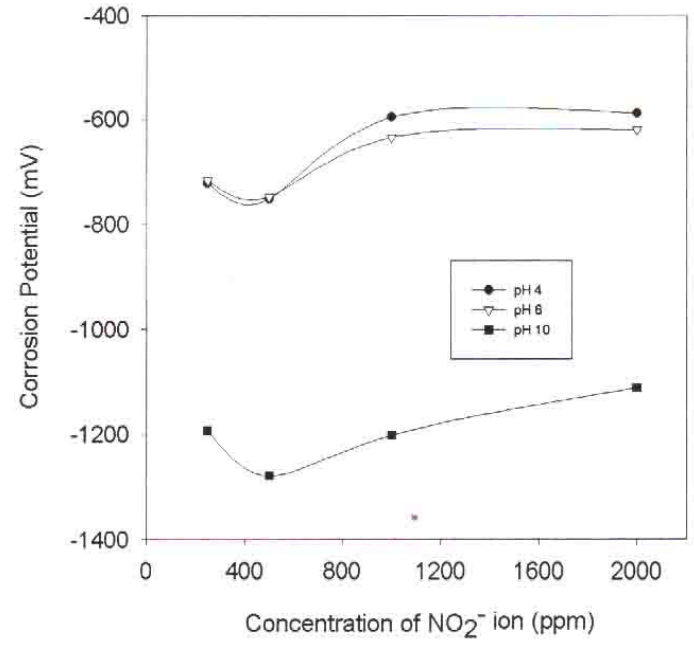

Figure 8: Effect of concentration of $\mathrm{NO}_{2}{ }^{-}$ion on the corrosion potential of aluminum in $1000 \mathrm{ppm}$ Clmedium at different $\mathrm{pH}$; soaking time $1 \mathrm{~h}$; area $3 \mathrm{~mm}^{2}$; temperature: $20 \pm 2^{\circ} \mathrm{C}$. 

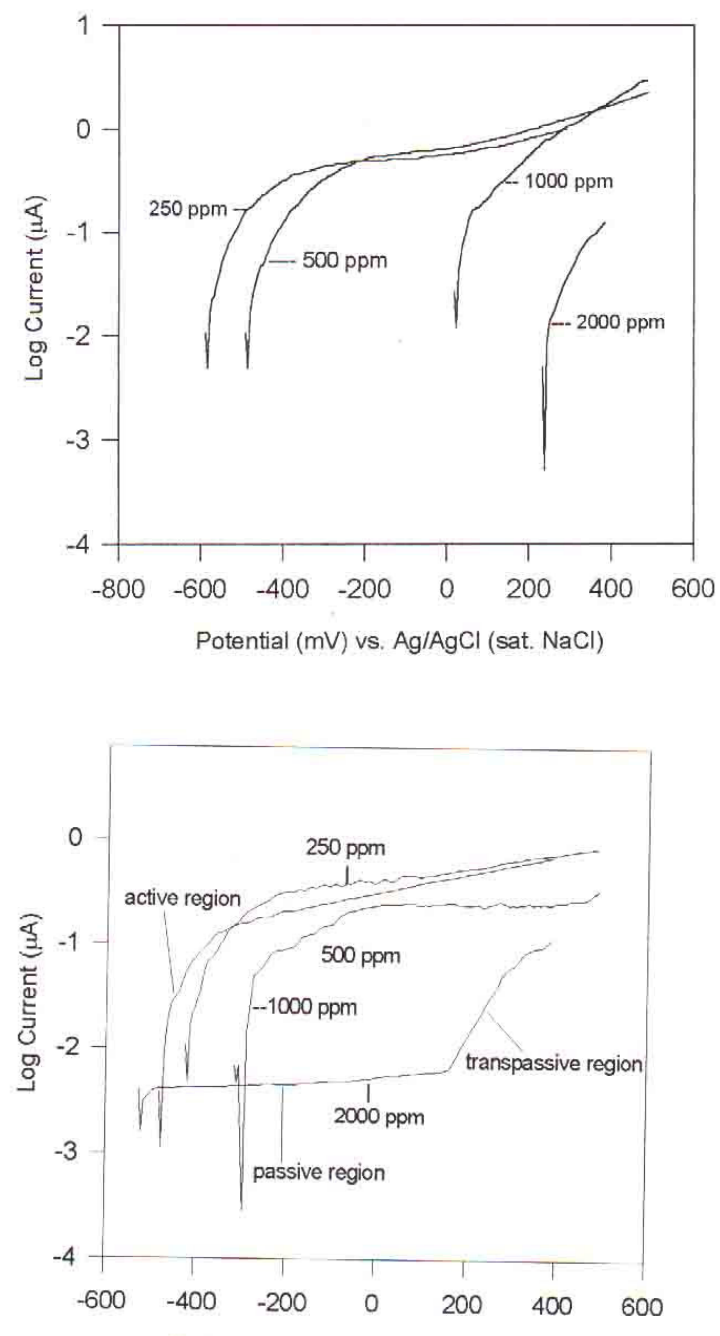

Potential ( $\mathrm{mV}$ ) vs. $\mathrm{Ag} / \mathrm{AgCl}$ (sat. $\mathrm{NaCl}$ )

\begin{tabular}{|c|c|}
\hline $\begin{array}{l}\text { Figure 9: Effect of concentration of } \mathrm{NO}_{2}^{-} \text {on } \\
\text { aluminum corrosion in } 500 \mathrm{ppm} \text { of } \mathrm{NO}_{3}^{-} \text {medium } \\
\text { at pH 6; soaking time } 1 \mathrm{~h} ; \text { area } 3 \mathrm{~mm}^{2} \text {; }\end{array}$ & $\begin{array}{l}\text { Figure 10: Effect of varying concentration of } \mathrm{NO}_{2}^{-} \\
\text {ion on the corrosion potential of aluminum in } 1000 \\
\text { ppm } \mathrm{NO}_{3}^{-} \text {medium at } \mathrm{pH} \text {; soaking time } 1 \mathrm{~h} \text {; area } \\
3 \mathrm{~mm}^{2} ; \text { temperature: } 20 \pm 2^{\circ} \mathrm{C} \text {. }\end{array}$ \\
\hline
\end{tabular}

Nitrite ion acts effectively as a corrosion inhibitor for aluminum corrosion and because of its powerful oxidizing properties, leads to form a stable oxide film. This reveals that surface oxide layer on the aluminum surface plays an important role on the corrosion inhibition in both $\mathrm{C}^{-}$and $\mathrm{NO}_{3}{ }^{-}$media. ${ }^{10}$ As aluminum corroded more at higher $\mathrm{pH}$ values in both the aggressive media, so the surface oxide layer assumed comparatively less stables at higher $\mathrm{pH}$ condition and inhibition observed more significant at lower $\mathrm{pH}$ in both the media. It means that nitrate as inhibitor acts promptly to reconstruct the affected surface oxide layer in any of the aggressive media at lower $\mathrm{pH}$ values, which was rather stable to passivate further corrosion reactions.

\section{Conclusions}


1. Polarization of aluminum surface cannot occur in aqueous media containing chloride and nitrate ions. On the other hand, depolarization increases with the increase of their $\left(\mathrm{Cl}^{-}\right.$and $\left.\mathrm{NO}_{3}{ }^{-}\right)$concentrations since they are all corrosive to aluminum.

2. In both the media, the surface oxide layer destroyed easily in lower acidic and higher basic $\mathrm{pH}$ values and it exposes metal surface to corrode severely. It is found that aluminum comparatively more corrodible in basic condition than in acidic condition.

3. Nitrite ion inhibits corrosion on aluminum surface at lower $\mathrm{pH}$ and the inhibition power of nitrite ion increases with concentration. The metal oxide layer corroded by pitting or localized corrosion is reformed in presence of nitrite, acts as a barriers layer and plays an important role by preventing oxidation reactions of metal ions on the surface.

\section{References}

1. H. H. Uhlig, Corrosion and Corrosion control' 85, London, Willey, 1967.

2. Von V. Ender and C. Wetzel, VGB Tech. Ver. Gross- Kraftwerkbret., 1998, R 6/1-R6/20.

3. V. Branzoi and M. V Popa, Mater. Corros., 2000, 51, 635.

4. Z. Bolanca and A. Hladnik, Some Properties of the Anodized Aluminum Surface; $15^{\text {th }}$ WCNDT conf., Roma, 2000.

5. E. Akiyama and G.S. Frankel, J. Electrochem. Soc., 1999, 146, 4095.

6. R.T. Foley and I.H Nguyen, J. Electrochem. Soc., 1982, 192, 129.

7. J. Bhattari, J. Nepal Chem.. Soc., 2000, 19, 32-41.

8. Et-Sayed, Abdel Rahman, Denki Kagaku Oyobi Kogyo Butsuri Kagaku, 1998, 66, 176.

9. F. M. Al-Kharafi, W. A. Badway, A.S. El-Azab, Cur.Top. Electrochem., 1997, 5, 131.

10. J. Shukla, K. S. Pitte, Ind. J. Chem., 1996, 35A, 44.

11. A. Hussam and A. H. Khan, UNDP-TOKTEN Report on Computerized Electrochemistry, Atomic Energy Centre, Dhaka, 1993. 